\title{
Mud Diapirism on the Makran, Iran: Case Study on the Napag Mud Volcano
}

\author{
Faranak Feizi1 ${ }^{*}$, Mehran Arian², Artin Arian³ \\ ${ }^{1}$ Department of Mining Engineering, Faculty of Engineering, South Tehran Branch, Islamic Azad University, \\ Tehran, Iran \\ ${ }^{2}$ Department of Geology, Science and Research Branch, Islamic Azad University, Tehran, Iran \\ ${ }^{3}$ Department of School Education, One Territory of Education Office, Ministry of Education, Tehran, Iran \\ Email: ${ }^{*}$ Feizi.faranak@yahoo.com
}

Received 16 April 2015; accepted 10 May 2015; published 13 May 2015

Copyright (C) 2015 by authors and Scientific Research Publishing Inc.

This work is licensed under the Creative Commons Attribution International License (CC BY).

http://creativecommons.org/licenses/by/4.0/

(c) (i) Open Access

\begin{abstract}
The Napag is the biggest Mud Volcano at Makran in Iran. The main aim of this research is the investigation of geologic setting and geographic situation of Napag Mud Volcano as a well-known mud diapir at Makran on the south eastern margin of Iran. The Napag Mud Volcano has been formed during quaternary of as a conical hill on the flat plain in coastal region Oman Sea. There are badlands area and several mud volcanoes that they have been triggered by longitudinal normal faults. This normal faults have been developed in neotectonic regime by the roll-back of oceanic lithosphere (beneath of Oman Sea). Finally, the main characteristics of the Napag mud diapir are presented.
\end{abstract}

\section{Keywords}

Napag, Mud, Volcano, Makran, Iran

\section{Introduction}

Mud Volcanoes are well-known phenomena whereby fluid-rich, fine-grained sediments ascend within a lithologic succession because of their buoyancy. These processes have long been recognized as being related to the occurrence of petroleum, regional volcanic and earthquake activity, and orogenic belts. Most importantly, mud volcanoes occur along convergent plate margins where fluid-rich sediment is accumulated in deep-sea trenches at high rates. Such deposits then enter the subduction factory, where liquids and volatiles are released due to increasing compaction stress and temperature.

\footnotetext{
${ }^{*}$ Corresponding author.
} 
In summary, mud volcanism is most abundant in compressional and, to a lesser extent, in deltas of great rivers. As for the first, tectonic activity is an additional trigger to the buoyant driving mechanism. Fluid for mud volcanism is supplied from various sources, including meteoric and volcanic waters, pore water expulsion, hot springs, mineral dehydration reactions, and gas hydrate destabilization [1]. The questions are, why and how mud-volcanoes form provokes a lively discussion. Many researchers have worked in different areas and postulated usually a variety of 4 - 7 reasons. All these reasons can be divided into four groups [2]:

1) Geologic reasons; 2) Tectonic reasons; 3) Geochemical reasons and 4) Hydrogeological reasons, i.e. fluid flow along fracture zones. It is easy to see that many of these reasons are closely related to each other or require the presence of each other. In various areas the reasons for mud volcano formation are different. As a consequence, it is pointless to define a universal limited set of reasons. The expedient approach is to determine the key causative factors that can be used to forecast the areas of mud volcanic activity.

\section{Materials and Methods}

Using the regularities in the spatial distribution of known and inferred submarine mud volcanoes we can define these two key reasons: 1) the high sediment accumulation rate at passive continental margins; 2) the lateral tectonic compression at active continental margins. All other conditions necessary for the formation of mud volcanoes (density inversion, faulting, fluid migration etc.) result from these two key reasons. In addition it is obvious that plastic clay layers must be present for mud volcanoes to form. In some regions, submarine mud volcanoes form in areas characterized by a spatial combination of rapid sediment accumulation and lateral tectonic compression [2].

Finding the characteristics of mud diapirs in the Makranregion in the south eastern part of Iran is the main aim in this research. This area is located on convergent tectonic setting between Cimmerian and oceanic part of Arabian plate (Figure 1). It contains the accretionary prism or Makran ranges on trench of Oman sea subduction zone.

Previous research on Iran's tectonic setting [4]-[6], salt diapirism [7]-[16], Seismotectonics [17]-[20] have

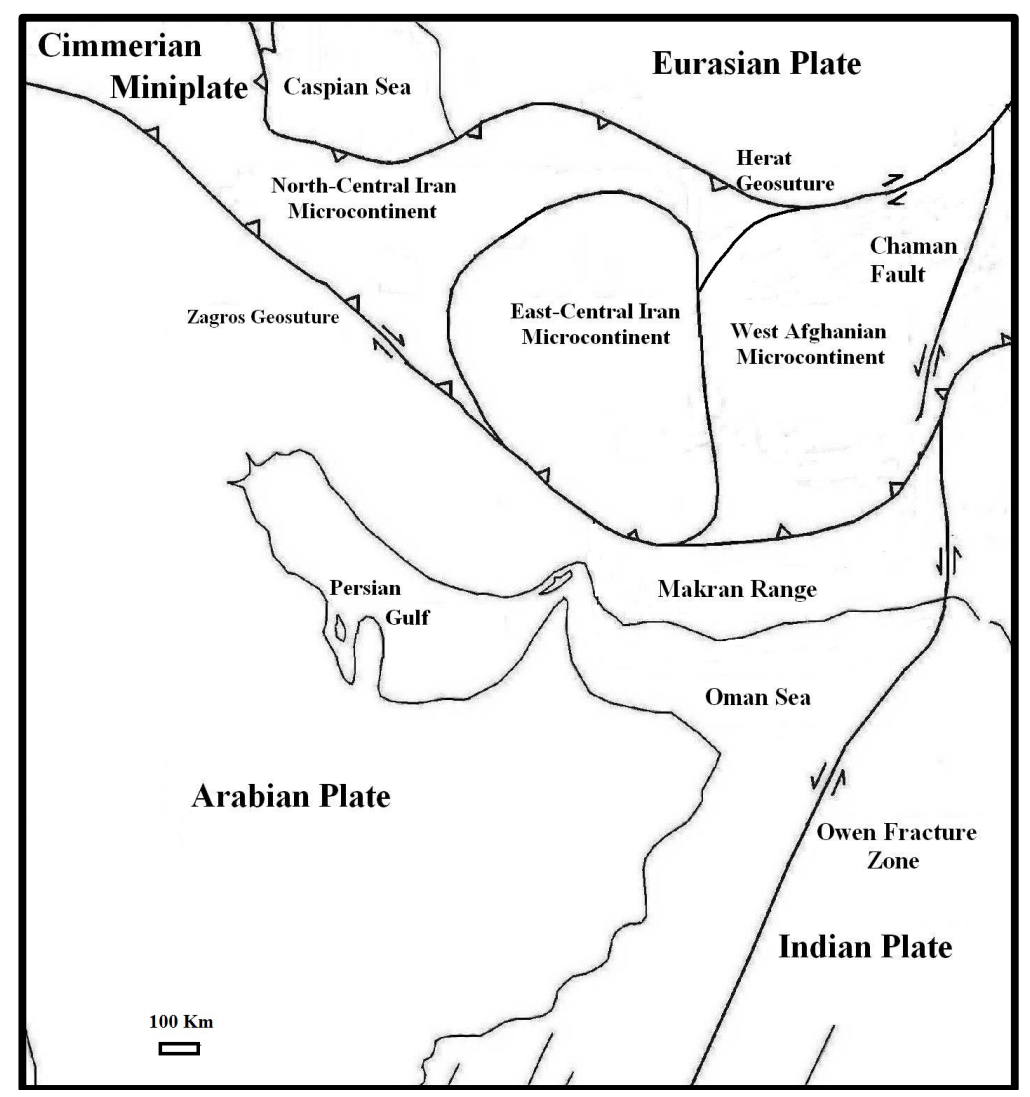

Figure 1. Tectonic framework map of Iran, modified from [3]. 
shown that the Zagros belt is the most active zone in Iran [21]-[30]. Alborz belt in north Iran [31]-[62] and Central Iran [63]-[75] have been situated in the next orders. But, Makran belt has been formed by the east-west striking accretionary prisms. It has been situated on trench of Oman sea subduction zone and there are several Mud volcanoes along the coastal part of Makranranges. The biggest one is Napag Mud volcano (Figure 2).

\section{Results and Discussion}

Based on our investigation, the Napag Mud Volcano have got a conical shape with 35 meters height (Figure 3) and it has been formed on the flat quaternary plain in coastal region (Figure 4) of Oman Sea. Flatted top of this cone has been developed by erosion (Figure 5). There is badlands area (Figure 6) at surrounding parts of mud volcanoes that they have formed by multistage mud eruptions (Figure 7).

In central part of the Napag Mud Volcano, gasbubbles are forming rapidly in a small pound that it has been filled by viscous clay (Figure 8).

Also, there are other badlands area and several mud volcanoes along coastal region Oman Sea that they have been triggered by longitudinal normal faults. The normal faults have been covered in quaternary flat but they have exposed in some place (Figure 9).

This normal faulting can be related to neotectonic regime of the southern flank of the Makran ranges that it has been controlled by the roll-back of oceanic lithosphere. It means that oceanic lithosphere beneath of Makran ranges has been sloped. In the other words, increasing of dip in Benioff zone, caused to recent normal longitudinal faulting on Makran accretionary Prism. The Mud volcanism in this region has been shown below specifications, based on our investigations.

This diapirs has been risefrom Paleocene to Late Miocene Turbidities and probably mud diapirism has been

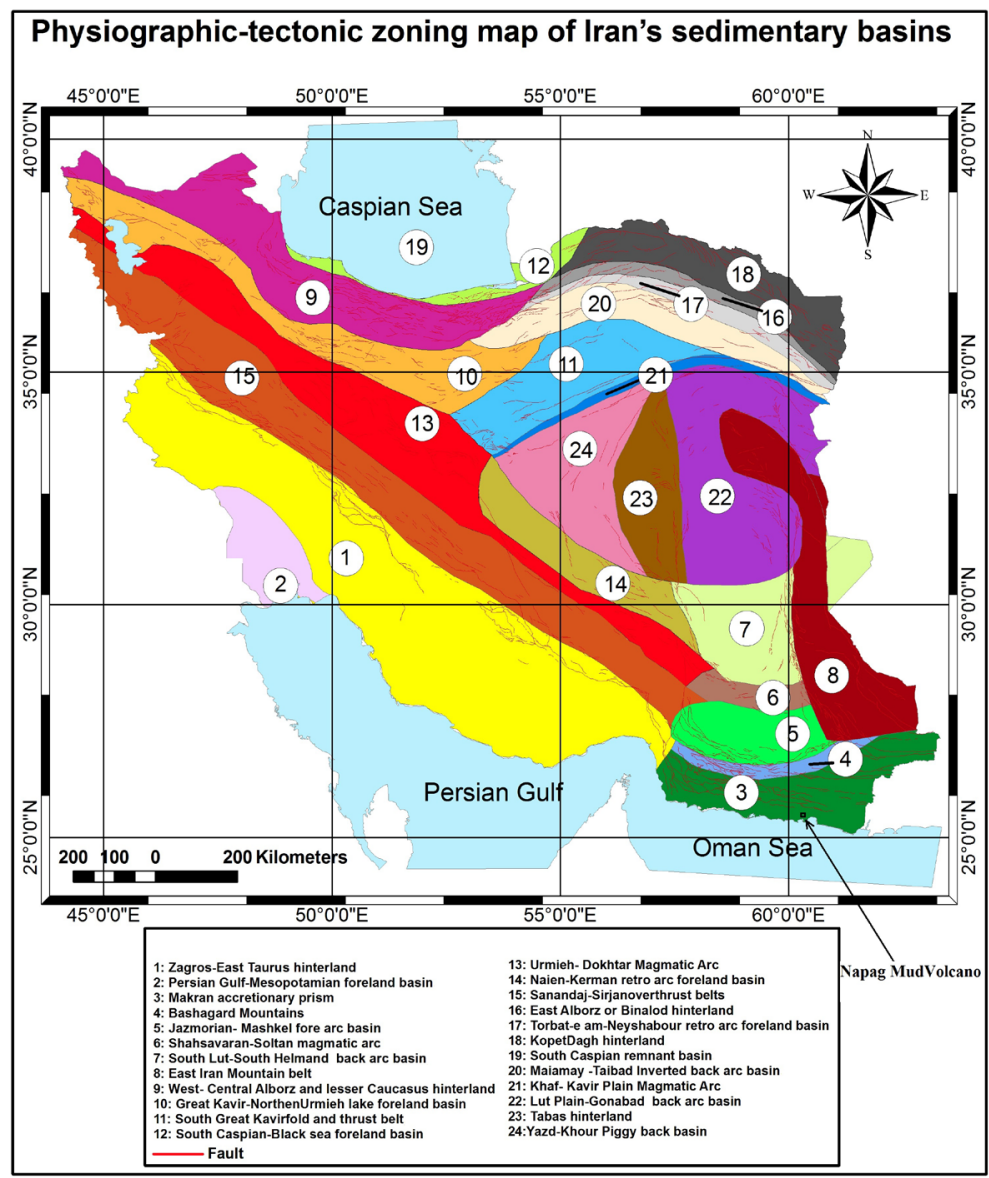

Figure 2. Physiographic-tectonic zoning map of Iran's sedimentary basins Iran modified from [3]. 


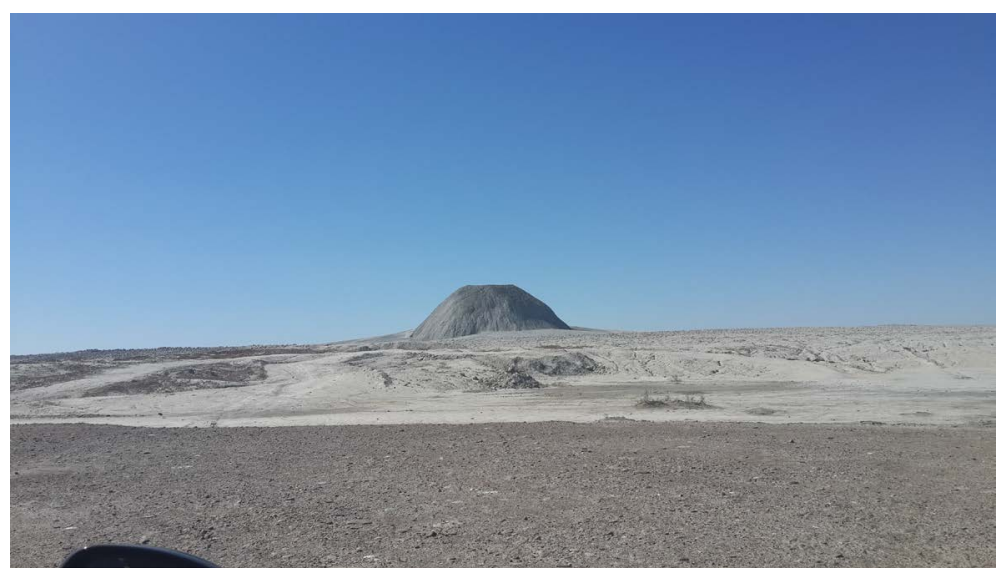

Figure 3. The Napag Mud volcanoat northwest of Konarak city, view to the north west.

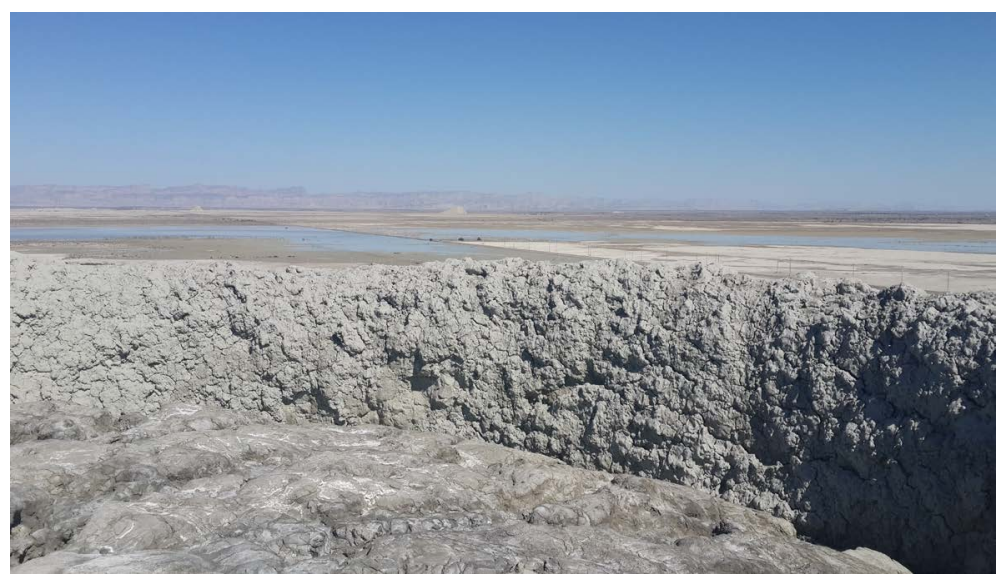

Figure 4. A view from top of the Napag Mud volcano to the north (Makran Range).

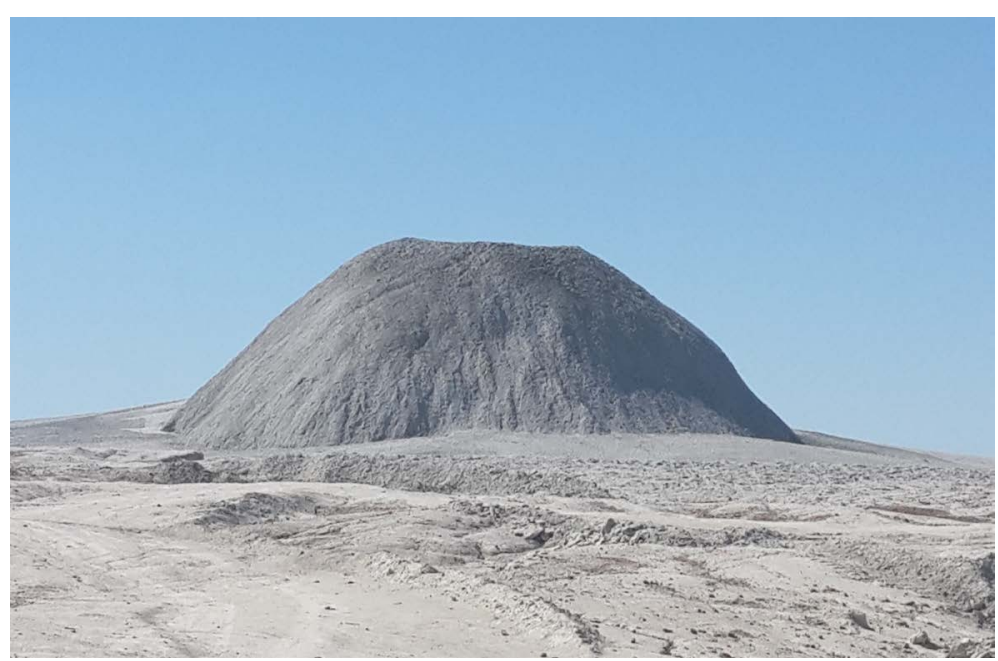

Figure 5. Flatted top of the Napag Mud volcano, view to the northwest.

started since Early Pliocene, because it has covered quaternary plain. Thrust Faults are the index structures in the makran region, but they have been cut by normal faults. It means that mud diapirs have been triggered by longi- 


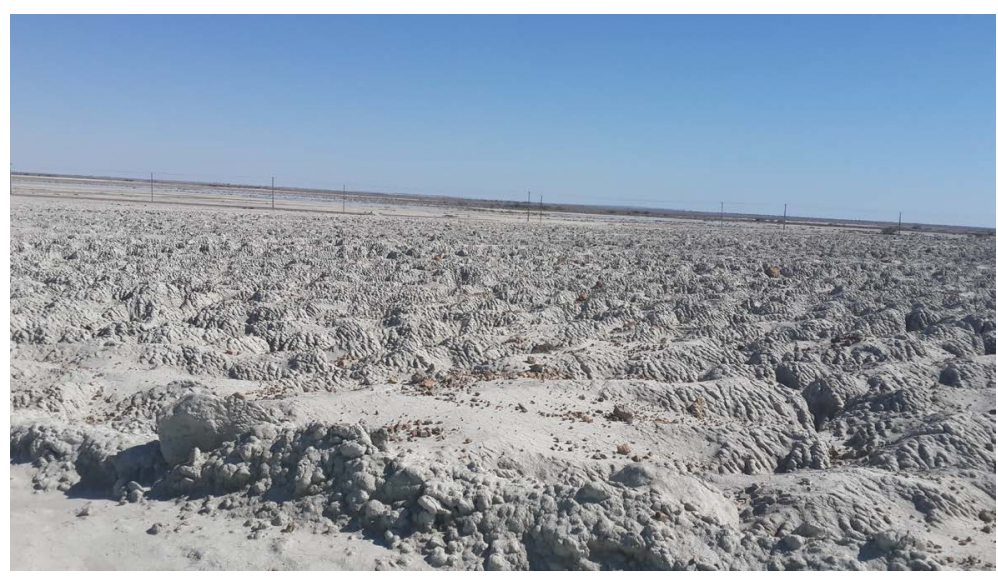

Figure 6. Badlands area at surrounding parts of the Napag Mud volcano, view to the east.
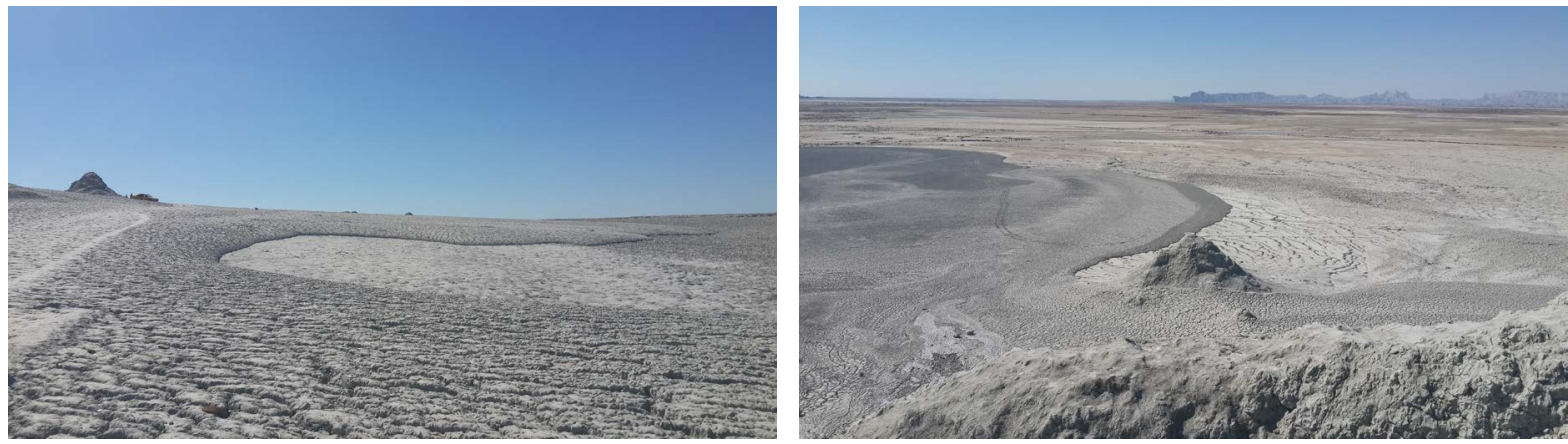

Figure 7. Two different view from multistage eruptions of the Napag Mud volcano.
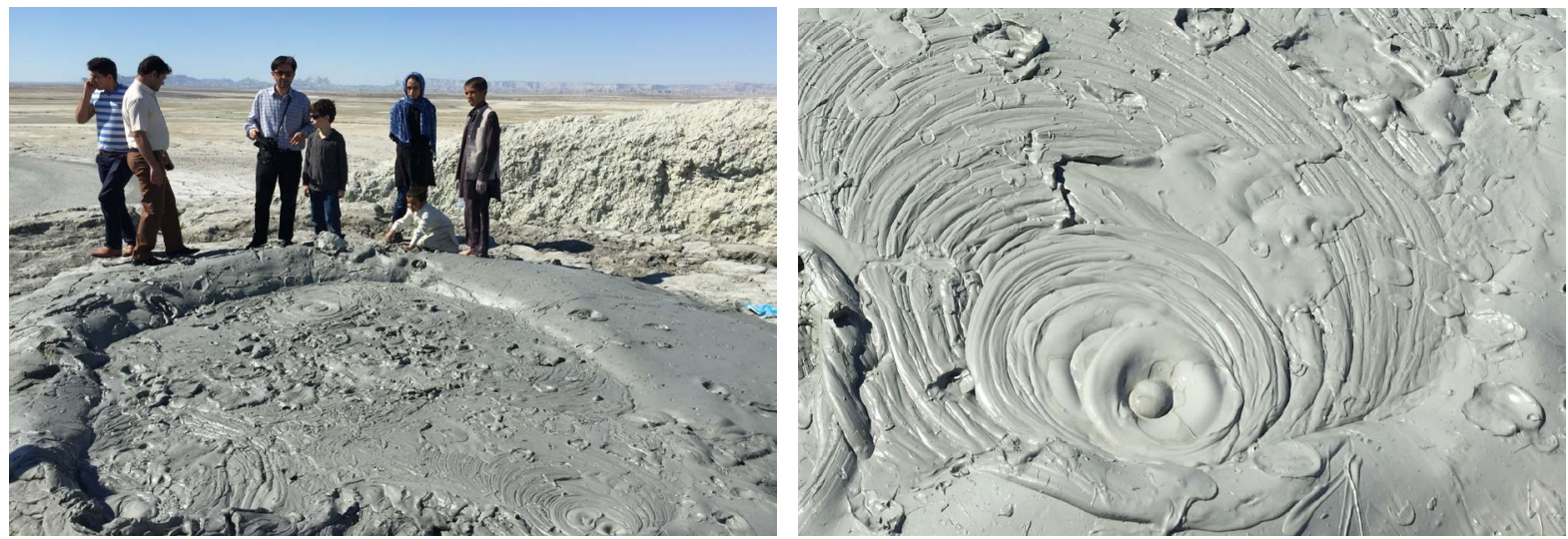

Figure 8. Two different view from viscous clay and gas bubbles in the central part of the Napag Mud volcano.

tudinal normal faults. There are several dispersed mud diapirs, but all of them are the smaller than Napag diaper.

\section{Conclusions}

Tectonic geomorphology and origin of the Napagmud volcano in Makran at South-eastern parts of Iran have been determinated. Mud diapirismin this zone has been controlled by tensional tectonic forces, that they have been cosiderable during roll-back of oceanic lithosphere in the Makran subducton zone.

It means that tectonic processes are predominant compared to buoyant driving mechanisms in the coastal parts of the Makran ranges. Therefore, formation of the new mud volcanoes and the more development of the older 


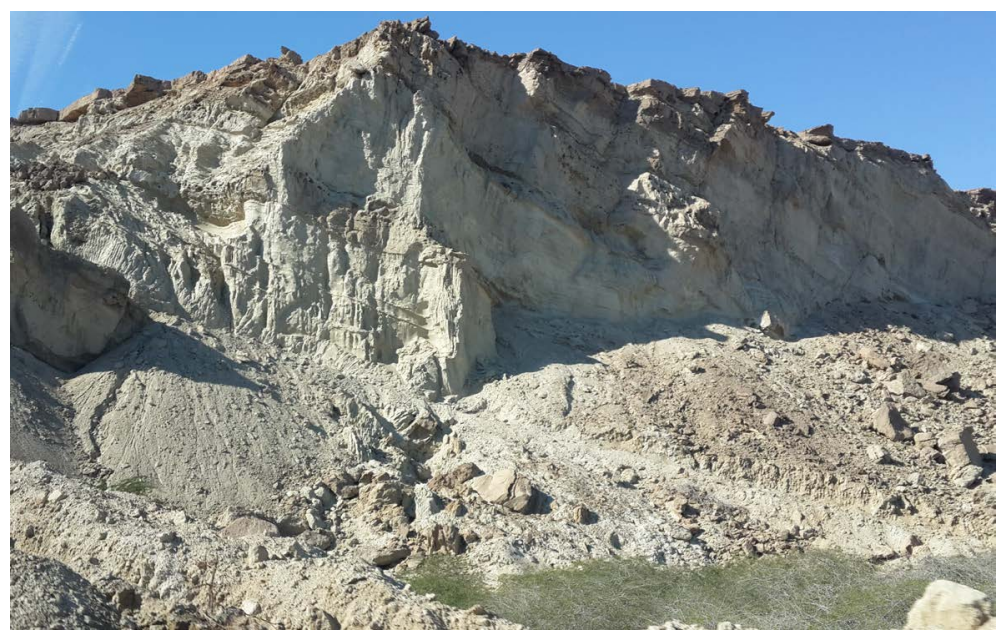

Figure 9. A normal fault that cropping out in the Makran accretionary Prism, view to the north west.

mud diapirs are expected. Because, during convergent between Cimmerian and oceanic part of Arabian plate, roll-back of oceanic lithosphere in the Makran subducton zone will increase in future.

\section{References}

[1] Kopf, A.J. (2002) Significance of Mid Volcanism. Reviews of Geophysics, 40, 52 p. http://dx.doi.org/10.1029/2000RG000093

[2] Milkov, A.V. (2000) Worldwide Distribution of Submarine Mud Volcanoes and Associated Gas Hydrates. Marine Geology, 167, 29-42. http://dx.doi.org/10.1016/S0025-3227(00)00022-0

[3] Arian, M. (2013) Physiographic-Tectonic Zoning of Iran’s Sedimentary Basins. Open Journal of Geology, 3, $169-177$. http://dx.doi.org/10.4236/ojg.2013.33020

[4] Arian, M. (2011) Middle East Tectonics. AsarNafis Press, Qum, 236 p.

[5] Qorashi, M. and Arian, M. (2011) Tectonics of Iran. Geologic Survey of Iran, Tehran, 336 p.

[6] Arian, M. (2011) Basement Tectonics and Geology of Iran. AsarNafis Press, Qum, 300 p.

[7] Arian, M. (2011) A Preface on Salt Diapirism of Iran. AsarNafis Press, Qum, 309 p.

[8] Arian, M. and Noroozpour, H. (2015) The Biggest Salt-Tongue Canopy of Central Iran. Open Journal of Geology, 5, 55-60. http://dx.doi.org/10.4236/ojg.2015.52005

[9] Asadian, F., Pourkermani, M. and Arian, M. (2007) Tectonic Geomorphology of Salt Structures in the GarmsarLasjerd Area. Geographical Research, 39, 75-84.

[10] Pourkermani, M. and Arian, M. (1997). Salt Domes of Central Iran. Journal of Humanities, 3, 29-41.

[11] Arian, M. (2012) Salt Diapirism and Tectonics. 2nd Edition, AsarNafis Press, Tehran, 319 p.

[12] Arian, M. and Noroozpour, H. (2015) Tectonic Geomorphology of Iran’s Salt Structures. Open Journal of Geology, 5, 61-72. http://dx.doi.org/10.4236/ojg.2015.52006

[13] Asadian, F. and Arian, M. (2009) Identification of Diapiric Provinces of Central Iran through Geological and Geographical Analysis. International Journal of Agriculture Environment \& Biotechnology, 2, 3443-3451.

[14] Arian, M. (2012) Clustering of Diapiric Provinces in the Central Iran Basin. Carbonates and Evaporites, 27, 9-18. http://dx.doi.org/10.1007/s13146-011-0079-9

[15] Pourkermani, M. and Arian, M. (1998) Tectonic Geomorphology of Salt Domes in West of Zanjan Province, Iran. Journal of Research Geography, 47, 44-53.

[16] Arian, M. and Feizi, F. (2010) The Significance of Faulting on the Surficial Spreading of Evaporitic Deposits in the Varamin-Semnan Area. Journal of Earth and Resources, 3, 1-20.

[17] Arian, M. and Maleki, R. (2008) Neotectonics. Farazamin Research Center, Tehran, 150.

[18] Pourkermani, M. and Arian, M. (1998) Seismicity of Iran. Shahid Beheshti University Press, Tehran, 212.

[19] Pourkermani, M. and Arian, M. (1997) Seismotectonics. Dez Ab Consulting Engineers Company Press, Tehran, 270. 
[20] Arian, M. (2010) Applied Seismotectonics. Farazamin Press, Tehran, 304 p.

[21] Arian, M. and Aram, Z. (2014) Relative Tectonic Activity Classification in the Kermanshah Area, Western Iran. Solid Earth, 5, 1277-1291. http://dx.doi.org/10.5194/se-5-1277-2014

[22] Mashal, M., Kermani, M.P., Charchi, A., Almasian, M. and Arian, M. (2013) Pattern of Structural Geology Underground in Eastern of North DEZFOL Embayment. Advances in Environmental Biology, 7, 260-268.

[23] Pazhoohan, M., Arian, M., Ghorashi, M. and Khosrotehrani, K. (2014) A Study of Drainage Pattern Responses to Active Tectonics in Tadvan Region, SW Iran. Geodynamics, 1, 36-41.

[24] Rahimi, N. and Arian, M. (2014) Tectonic Geomorphplogy of Hamedan-Sosangerd Region, West Iran. Advances in Environmental Biology, 8, 119-124.

[25] Arian, M. and Hashemi, A. (2008) Seismotectonic Zoning in the Zagros. Journal of Sciences, 18, 63-76.

[26] Arian, M., Ahmadnia, A., Qorashi, M. and Pourkermani, M. (2002) Structural Analysis of Mengharak Transcurrent Fault System in Zagros, Iran. Special Geo 2002 Conference Issue Geoarabia, 7, 209-210.

[27] Arian, M., Qorashi, M., Pourkermani, M. and Ahmadnia, A. (2003) Fractal Analysis of Mengharak Transcurrent Fault System in Zagros, in Iran. Abstracts of 4th International Conference on Seismology and Earthquake Engineering, 4-6 May 2003, Tehran, 23.

[28] Baharvand, S., Pourkermani, M., Ajalloian, R., Arian, M. and Nouryazdan, A.R. (2010) Seymareh Landslide and Its Role in Environmental and Geomorphologic Changes of the Pole-Dokhtar Area. Journal of the Earth, 4, 13-24.

[29] Abdideh, M., Qorashi, M., Rangzan, K. and Arian, M. (2011) Assessment of Relative Active Tectonics using Morphometric Analysis, Case Study of Dez River (Southwestern, Iran). Geosciences Scientific Quarterly Journal, 20, 33-46.

[30] Arian, M., Qorashi, M., Pourkermani, M. and Ahmadnia, A. (2006) The Structural Significance Kareh Bas Transcurrent Fault System in the Zagros Fold and Thrust Belt. Journal of Geosciences, Geological Survey of Iran, 15, 126-133.

[31] Arian, M., Maleki, Z. and Noroozpour, H. (2011) Cenozoic Diastrophism and Deformational Events in the East Central Alborz. Journal of Basic and Applied Scientific Research, 1, 2394-2400.

[32] Feizi, F., Arian, A. and Rahmani, R. (2007) Seismotectonic Zoning in the Eastern Part of the Central Alborz. Journal of Sciences (Islamic Azad University), 17, 151-164.

[33] Khavari, R., Arian, M. and Ghorashi, M. (2009) Neotectonics of the South Central Alborz Drainage Basin, in NW Tehran, N Iran. Journal of Applied Sciences, 9, 4115-4126. http://dx.doi.org/10.3923/jas.2009.4115.4126

[34] Arian, M. and Bagha, N. (2012) Active Tectonics of Tehran Area, Iran. Journal of Basic and Applied Scientific Research, 2, 3805-3819.

[35] Bagha, N., Arian, M., Ghorashi, M., Pourkermani, M., El Hamdouni, R. and Solgi, A. (2014) Evaluation of Relative Tectonic Activity in the Tehran Basin, Central Alborz, Northern Iran. Geomorphology, 213, 66-87. http://dx.doi.org/10.1016/j.geomorph.2013.12.041

[36] Arian, M. and Feizi, F. (2005) Application of Geomorphic Indices to the Assessment of Relative Tectonic Activity Levels in the Alborz-Central Iran Border Zone (from the East of Varamin to the East of Semnan). Journal of Sciences (Islamic Azad University), 15, 378-403.

[37] Arian, M., Bagha, N., Khavari, R. and Noroozpour, H. (2012) Seismic Sources and Neo-Tectonics of Tehran Area (North Iran). Indian Journal of Science and Technology, 5, 2379-2383.

[38] Moghimi, H., Arian, M. and Sorbi, A. (2015) Fault Movement Potential of Marzanabad Area, North Alborz, Iran. Open Journal of Geology, 5, 126-135. http://dx.doi.org/10.4236/ojg.2015.53012

[39] Arian, M. and Pourkermani, M. (2004) Tectonic Elements of South Flank in the East-Central Alborz Mountain. Journal of Sciences (Teacher Training University), 4, 359-368.

[40] Arian, M. and Qorashi, M. (2006) The Movement Potential Evaluation of the Major Quaternary Faults in Alborz-Central Iran Border Zone, from the East of Tehran to the East of Semnan. Journal of Geosciences, Geological Survey of Iran, 15, 184-188.

[41] Poroohan, N., Pourkermani, M. and Arian, M. (2013) An Assessment of Relationship in F-Parameter and Paleostress Fields in Heterogeneous Lithologies: Roudbar Area (Northwest of Iran). Australian Journal of Basic \& Applied Sciences, 7, 933-942.

[42] Poroohan, N., Poukermani, M. and Arian, M. (2009) An Assessment on Correlations of Seismotectonic Parameters Preceding and Following Roudbar-Manjil Earthquake (Gilan, North of Iran). Australian Journal of Basic \& Applied Sciences, 3, 2643-2652.

[43] Farrokhnia, A.R., Pirasteh, S., Pourkermani, M. and Arian, M. (2011) Geo-Information Technology for Mass Wasting Hazard Zonation: Central-West Alborz-Iran. Disaster Advances, 4, 24-33.

[44] Khavari, R., Ghorashi, M. and Arian, M. (2009) Assessment of Relative Active Tectonics, South Central Alborz (North 
Iran). EGU General Assembly 2009, Vienna, 19-24 April 2009.

[45] Sorbi, A., Arian, M. and Pourkermani, M. (2009) The Movement Potential Evaluation of the Major Quaternary Faults in Tehran Quadrangle. Journal of the Earth, 19, 176-182.

[46] Feizi, F. and Arian, M. (2006) The Classification of Thrust Fronts in the Alborz-Central Iran Border Zone from the East of Varamin to the East of Semnan. Journal of Sciences, 16, 75-87.

[47] Arian, M. and Feizi, F. (2005) Application of Geomorphic Indices to the Assessment of Relative Tectonic Activity Levels in the Alborz-Central Iran Border Zone the Alborz-Central Iran Border Zone (from the East of Varamin to the East of Semnan). Journal of Sciences, 15, 378-403.

[48] Arian, M. and Pourkermani, M. (2004) Structural Significance of North Semnan and Attary Faults in Alborz-Central Iran Border Zone. Journal of Sciences (Islamic Azad University), 14, 4551-4569. (In Persian)

[49] Arian, M. and Pourkermani, M. (2005) Cenozoic Diastrophism and Deformational Events in the Southern Flank of Central-East Alborz. Journal of Faculty of Earth Sciences, 10, 43-51.

[50] Arian, M., Pourkermani, M., Qorashi, M. and Ghasemi, M.R. (2003) North Semnan Fault System and Its Role on Basin Division. 8th Symposium of Geological Society of Iran, Vol. 2, Shahrood, September 2004, 11-17.

[51] Pourkermani, M. and Arian, M. (2001) Structural Geomorphology of Northeastern Kurdistan, Sistan and Baluchestan University. Journal of Humanities, 7, 37-48.

[52] Mardani, Z., Ghorashi, M. and Arian, M. (2011) Geomorphic Signatures of Active Tectonics in the Talaghan Rud, Shah Rud and Sefidrud Drainage Basins in Central Alborz, Niran. Geosciences, 20, 159-166.

[53] Sorbi, A., Arian, M. and Pourkermani, M. (2011) The Application of Geomorphic Indices to the Assessment of Relative Tectonic Activity Levels in Tehran Quadrangle. Journal of the Earth, 6, 1-9.

[54] Khavari, R., Ghorashi, M., Arian, M. and Khosrotehrani, K. (2010) Geomorphic Signatures of Active Tectonics in the Karaj Drainage Basin in South Central Alborz, Niran. Geosciences Scientific Quarterly Journal, 19, 67-74.

[55] Javadi Mousavi, E. and Arian, M. (2015) Tectonic Geomorphology of Atrak River, NE Iran. Open Journal of Geology, 5, 106-114. http://dx.doi.org/10.4236/ojg.2015.53010

[56] Nouri, R., Jafari, M.R., Arian, M., Feizi, F. and Afzal, P. (2013) Correlation between Cu Mineralization and Major Faults Using Multifractal Modelling in the Tarom Area (NW Iran). Geologica Carpathica, 64, 409-416. http://dx.doi.org/10.2478/geoca-2013-0028

[57] Nouri, R., Jafari, M.R., Arian, M., Feizi, F. and Afzal, P. (2013) Prospection for Copper Mineralization with Contribution of Remote Sensing, Geochemical and Mineralographical Data in Abhar 1:100,000 Sheet, NW Iran. Archives of Mining Sciences, 58, 1071-1084. http://dx.doi.org/10.2478/amsc-2013-0074

[58] Nouri, R., Afzal, P., Arian, M., Jafari, M. and Feizi, F. (2013) Reconnaissance of Copper and Gold Mineralization Using Analytical Hierarchy Process (AHP) in the Rudbar 1:100,000 Map Sheet, Northwest Iran. Journal of Mining and Metallurgy A: Mining, 49, 9-19.

[59] Arian, M. and Nouri, R. (2015) Lineament Tectonics and Mineralizatin in Tarom Area, North Iran. Open Journal of Geology, 5, 115-124. http://dx.doi.org/10.4236/ojg.2015.53011

[60] Feizi, F. and Arian, M. (2011) The Role of Structural Controllers in Geneses of Copper Deposits in 1:50000 Map of Saiin Qaleh. Journal of Sciences, 21, 1-10.

[61] Bahiraee, S., Arian, M., Qorashi, M. and Solgi, M. (2015) The Movement Potential Evaluation of the Mosha Fault (the West of Firoozkuh to the Shahrestanak). Geosciences, 24, 123-126.

[62] Bagha, N., Ghorashi, M., Arian, M., Pourkermani, M. and Solgi, A. (2015) Neotectonic Analysis of Mosha-North Tehran Fault Zone, Based on Morphotectonic Features, Central Alborz, Northern Iran. Geosciences, 24, 41-52.

[63] Arian, M., Toudeshki, V.H. and Noroozpour, H. (2011) Active Tectonics of Qezel Ozan River Basin, NW Iran. Journal of Applied Environmental and Biological Sciences, 1, 291-295.

[64] Toudeshki, V.H., Pourkermani, M., Arian, M. and Khosrotehrani, K.H. (2011) Influence of Structures on the Ghezel Ozan River. Geosciences, 21, 55-60.

[65] Toudeshki, V.H. and Arian, M. (2011) Morphotectonic Analysis in the Ghezel Ozan River Basin, NW Iran. Journal of Geography and Geology, 3, 258-260.

[66] Mosavi, E.J. and Arian, M. (2015) Neotectonics of Tabas Area, Central Iran by Index of Active Tectonics (IAT). Open Journal of Geology, 5, 209-223. http://dx.doi.org/10.4236/ojg.2015.54019

[67] Daryani, N.J., Arian, M. and Omran, N.R. (2015) Tectonics and Mineralization of Copper in the Ardestan-Kahang Area, Central Iran by Remote Sensing. Open Journal of Geology, 5, 188-196. http://dx.doi.org/10.4236/ojg.2015.54017

[68] Arian, M. and Pourkermani, M. (2001) Rivers Morphology and Active Tectonic (Reviewing the Current Status of Ghezel Ozon River in the Province of Zanjan). 5th Conference of Geological Society of Iran, Tehran, 28-30 August 
2001, 556.

[69] Eshghi, Z., Arian, M. and Pourkermani, M. (2012) Structural Investigation on the Lak Mining Area (Bueen Zahra) Based on Remote Sensing, Used for Its Mineralization. Journal of the Earth, 6, 145-155.

[70] Arian, M., Toudeshki, V.H. and Noroozpour, H. (2011) Active Tectonics of Qezel Ozan River Basin, NW Iran. Journal of Applied Environmental and Biological Sciences, 1, 291-295.

[71] Alizadeh, H., Arian, M., Lotfi, M., Ghorashi, M. and Ghorbani, M. (2015) Determination of Porphyry Copper Deposit Locations Using Photo Lineament Factor in Northern Parts of the Dehaj-Sardoiyeh Belt. Geosciences, 24, $247-252$.

[72] Mosavi, E.J., Arian, M., Ghorashi, M. and Nazemi, M. (2012) Measurements of Geomorphic Indices in Tabas Area. Journal of the Earth, 7, 213-225.

[73] Arian, M. (2010) Earthquake-Fault Hazard Investigations in the Kerman Quadrangle. Journal of Sciences, Islamic Azad University, 19, 176-182.

[74] Arian, M., Pourkermani, M., Sistanipour, A. and Noroozpour, H. (2011) Kinematic Significance of Fold- and FaultRelated Fracture Systems in the Rafsanjan’s Northeast Highlands (Central Iran). Journal of Basic and Applied Scientific Research, 1, 3398-3406.

[75] Arian, M., Pourkermani, M., Sistanipour, A. and Noroozpour, H. (2011) Seismicity and Fault Segmentation of BafqBaghin Fault System (Central Iran). Journal of Applied Environmental and Biological Sciences, 1, 382-396. 